Volume 9 Part 1 March 1989

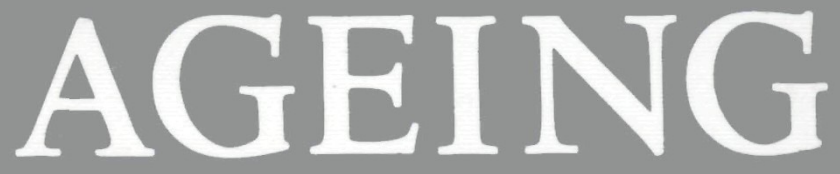

AND

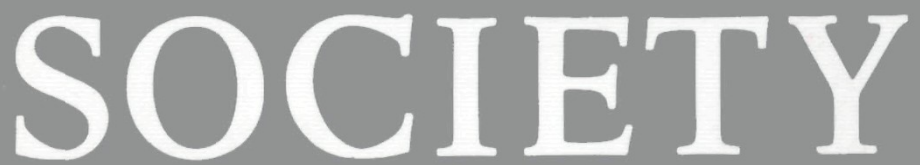




\title{
AGEING AND SOGIETY
}

\author{
The Journal of \\ The Centre for Policy on Ageing and The British Society of Gerontology
}

Editor: MALCOLM L. JÖHNSON

Professor of Health and Social Welfare, The Open University, Walton Hall, Milton Keynes, MK $76 A A$, England

\author{
Review Editor: ANTHONY M. WARNES \\ Age Concern Institute of Gerontology, King's College London, 552 King's Road, London SWIo oUA, \\ England
}

\author{
Editorial Board \\ Alan Butler (University of Leeds) \\ Peter Coleman (University of Southampton) \\ Gillian Crosby (Centre for Policy on Ageing, London) \\ Michael Fogarty (Red Copse, Foxcombe Road, Boarshill, Oxford) \\ Margot Jefferys (32 Bisham Gardens, London) \\ Leonie Kellaher (Polytechnic of North London) \\ Peter Laslett (Trinity College, University of Cambridge) \\ Peter Millard (St. George's Hospital Medical School, London) \\ Robert Pinker (London School of Economics) Chairman \\ Patrick Rabbitt (University of Manchester) \\ Paul Spencer (University of London) \\ Rex Taylor (University of Glasgow) \\ Susan Tester (Centre for Policy on Ageing, London) \\ Deirdre Wynne-Harley (Centre for Policy on Ageing, London) \\ Overseas Editorial Advisers \\ Eva Beverfelt (Institute of Gerontology, Oslo) \\ James Birren (University of Southern California) \\ Françoise Cribier (Université de Paris) \\ Michael Davies (National Institute on Ageing, Bethesda) \\ Carroll Estes (University of California, San Francisco) \\ Anna Howe (La Trobe University, Australia) \\ Daisaku Maeda (Metropolitan Institute of Gerontology, Tokyo) \\ Victor Marshall (University of Toronto) \\ J. M. A. Munnichs (Katholieke Universiteit, Nijmegen) \\ Leopold Rosenmayr (University of Vienna)
}

Ageing and Society is an international journal devoted to publishing contributions to the understanding of human ageing, particularly from the social and behavioural sciences and humanities. Its interpretation of ageing is wide and includes all aspects of the human condition whether they relate to individuals, groups, institutions or societies.

In addition to original articles the journal also carries a review section comprising book reviews and shorter notes, review articles and symposia, and an abstracts service intended to draw readers' attention to relevant articles in other journals.

Copying: This journal is registered with the Copyright Clearance Center, 27 Congress St., Salem, Mass. or 970. Organizations in the USA who are also registered with C.C.C. may therefore copy material (beyond the limits permitted by sections 107 and 108 of US copyright law) subject to payment to C.C.C. of the per-copy fee of $\$ 5.00$. This consent does not extend to multiple copying for promotional or commercial purposes. Code or $44-686 \mathrm{X} / 89 \$ 5.00+.00$.

For all other use, permission should be sought from Cambridge or the American Branch of Cambridge University Press.

Subscriptions: Ageing and Society (ISSN o1 44-686X) is published in volumes of four parts in March, June, September and December. The subscription price (which includes postage) of volume 9,1989 is $£ 45.00$ in U.K., $£ 49.00$ elsewhere. (US $\$ 82.00$ in USA and Canada) for institutions, $\ell_{25} .00$ (US $\$ 38.00$ in USA and Canada) for individuals ordering direct from the Press and certifying that the journal is for their personal use. Single parts cost $£$ I 3 .oo net (US $\$ 22.00$ in USA and Canada) plus postage. Orders, which must be accompanied by payment, may be sent to a bookseller, subscription agent or direct to the publishers: Cambridge University Press, The Edinburgh Building, Shaftesbury Road, Cambridge CB$_{2} 2$ RU. Orders from the USA or Canada should be sent to Cambridge University Press, 32 East 57th Street, New York, NY r 0022 , USA. Copies of the journal for subscribers in the USA and Canada are sent by air to New York to arrive with minimum delay. Second class postage paid at New York, NY, and at additional mailing offices.

Postmaster: Send address changes in USA and Canada to Ageing and Society, Cambridge

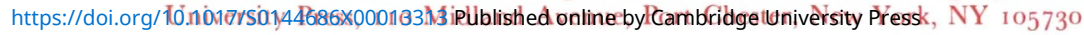

